\title{
Joggyakorlat
}

\author{
DeÁK DÁNIEL*
}

\section{Környezeti adóharmonizáció és versenykonform szabályozás az Európai Unió Bírósága gyakorlatának fényében}

\begin{abstract}
környezeti adóharmonizáció - ökoadó - parafiskális irányítási eszköz - szelektív állami intézkedés - határon átnyúló termékadó
\end{abstract}

\begin{abstract}
A környezeti adók alkalmazása kihívás a gazdaságpolitika számára, amellyel szemben támasztható elvárás piacgazdasági viszonyok között a gazdasági növekedés biztosítása. Ez az elvárás viszont tendenciájában ellentmond az ökológiai egyensúly kívánatos fenntartásának. A fenntartható fejlődés jegyében bevezetett gazdaságpolitika ugyan azt a kincstári optimizmust sugározza, hogy a növekedés és a környezeti egyensúly szempontjai egymással összebékíthetők, az egyre nyomasztóbb ökológiai válság tényei azonban nyomatékosan figyelmeztetnek bennünket a gazdasági növekedés termodinamikai korlátaira. Az alábbi tanulmány tárgya általában véve a környezeti adók - az ökológiai válságra reflektálva az ökoadók - alkalmazásának magyarázata és igazolása, különösen pedig az európai fejlemények felmérése és az Európai Bíróság ez irányú gyakorlatának vizsgálata.

Kézenfekvő foglalkozni az ökoadók alkalmazásának az ezredfordulót követő években kialakult elvi kérdéseivel és gyakorlatával. Az ezt kiegészítő másik tárgy a jövő lehetőségeinek számbavétele. Globális alternatívát keresve a világkapitalizmus problémáira reflektálunk, és a nemzetállamon túlmutató problémák és szabályozási lehetőségek után kutatunk. Ez utóbbi azonban egy másik tanulmány tárgya lehet. Ma még ugyan lehetséges környezeti adók alkalmazása különösebb elvi megalapozás nélkül, de a puszta pragmatizmus alapján nem hozható létre fenntartható környezeti politika. Tanulmányom érvanyagot szállít ahhoz, hogy a jövőben lehetséges legyen az ökoadók megalapozása immár nem piaci alapon, hanem ökológiai szemléletben.
\end{abstract}

* Dr. Deák Dániel egyetemi tanár, Budapesti Corvinus Egyetem, daniel.deak@uni-corvinus.hu. 


\section{Bioszféra, környezeti politika és adóztatás}

A természetet megélö, az élölényekkel és élettelen környezettel együtt létező ember felelőssége, hogy ahol szükséges, beavatkozzék. A napi életünkben feltűnő problémák különösen az energiaválság, a környezetszennyezés, a munkanélküliség és kriminalitás, ezek pedig mind összefüggenek egymással. A jelenleg megtapasztalt ökológiai válság korszakváltások halmaza, amelyben összegződnek az egyéni, társadalmi, civilizációs és planetáris problémák, és amelynek kiváltó okai többek között az egyoldalú érzékelésen alapuló materialisztikus kultúra vége, a fosszilis energia felhasználásának korlátai és a patriarchális társadalom válsága. ${ }^{1}$

A bioszféra, az emberi tevékenység és a gazdaság ökológiailag értelmezhető kapcsolatára a kölcsönös függőség jellemző; ${ }^{2}$ a bioszféra az ember számára

- forrást biztosít (energiát és anyagot szolgáltat az emberi tevékenységhez);

- elszívó hatást fejt ki (a talaj, a víz és a levegő fölveszik a szennyező anyagokat és az elhasznált energiát);

- az ökoszisztéma szintjén szolgáltatásokat nyújt (ózonpajzsot és klímastabilitást biztosít).

A fenti adottságokhoz igazodik a környezeti adóztatás, amely a következőkben nyilvánul meg:

- energiaadóztatás és a természeti erőforrások használatának adóztatása;

- hulladékgazdálkodással összefüggő adóztatás;

- karbontermékek adóztatása, az üvegházhatást csökkentendő.

Ha a bioszféra nem képes betölteni a forrásbiztosító, elszívó és egyensúlyi funkcióit, akkor az emberi élet, és benne a gazdaság fenntarthatatlan, amire tekintettel az embernek le kell lassítania az energia és anyag mobilizálásának ütemét, ami dematerializálás és leválasztás (decoupling) révén valósítható meg. ${ }^{3}$ Dematerializálás valósul meg a felhasznált természeti erőforrások tömegének csökkentése révén, leválasztás valósul meg akkor, ha azt az arányt lehetséges csökkenteni, amely a felhasznált erőforrások tömege és a felhasználásukkal nyert új érték között áll fenn, tehát a felhasználás nemcsak kiterjedésben, hanem intenzitásban is csökkenthetö. ${ }^{4}$ A relatív leválasztás (relative decoupling) azt jelenti, hogy az eröforrás-felhasználás méreteiben nem csökken, de az új érték előállításához képest javulás áll be azáltal, hogy kevesebb erőforrás felhasználásával sikerül előallítani egységnyi értéket. Abszolút leválasztás (absolute decoupling) esetén az erőforrások felhasználása összességében csökken, és nem csak a környezetkímélés intenzitása javul.

1 Lásd CAPRA, Fritjof: The Turning Point. Bantam, New York, 1984 (reissue edition), 4. http://truegyan.weebly. com/uploads/5/6/0/2/560238/the_turning_point_by_fritjof_capra.doc (2015. 12. 23.).

2 EkINs, Paul: Introduction to the Issues and the Book. In: Ekins, Paul-Speck, Stefan (eds.): Environmental Tax Reform. Oxford University Press, Oxford, 2011, 4-5; DaLY, Herman E.: From Empty World to Full World Economics. In: Goodland, Robert-Daly, Herman E.-Serafy, Salah El (eds.): Population, Technology and Lifestyle: The Transition to Sustainability. Island Press, Washington, DC, 1992, 5.

3 EKINS: i. m., 6.

4 EKINS: i. m., 6. 
Az abszolút leválasztás dematerializálásnak, vagyis zsugorodó gazdaságnak feleltethető meg. Növekvő gazdaságban a dematerializálás abszolút leválasztással jár együtt, csökkenő gazdaságban az összefüggés nem egyértelmü, hiszen nem tudjuk, hogy az eröforrás-felhasználás tömegében való csökkentésével vajon együtt járt-e a felhasználás környezeti intenzitásának csökkentése, mivel az előállított új érték mennyisége is csökken. A felhasználandó erőforrások lehetnek szűzek (a természetből közvetlenül kinyertek), újrahasznosításból származók vagy értéküket veszített erőforrások (hulladék). ${ }^{5}$

Az ökológiai helyzet felmérése nem könnyű, mert nem csupán a természet állapotáról van szó, hanem benne az emberröl, aki dinamikus módon viszonyulva a természethez, annak maga is alakítója. Fritjof Capra szerint az óramü szintén autonóm, legalábbis elszigetelt környezetétöl, és energia kell müködtetéséhez, de az óra müködéséhez nincs szükség önreferálás és interakciók útján kialakítandó zárt információs rendszerre. Az óramű az entrópia törvénye szerint létezésének folyamatában halad a rendtöl a káosz, illetve a dinamikus egyensúlytalansági állapottól az egyensúlyi állapot felé, amíg egyszer csak megszünik müködni és létezni. $A z$ élő szervezet viszont nyitott rendszer, amely a folytonos energia- és anyagcsere állapotában van (metabolizmus). Az ilyen élö rendszer addig vitális, amíg az alkotó egyensúlytalanság dinamikus állapotában van. ${ }^{6}$

Az élet és természeti környezetének nyomon követése arra a belátásra vezet bennünket, hogy a természeti struktúrák és funkciók mellett rámutassunk a mentáció, ${ }^{7}$ a szükségképpeni adaptáció mellett a kreáció, az önszerveződés lehetőségére. Ez azt jelenti, hogy a természetbe való beavatkozás nem egyszerúen az emberi cselekvés tárgya. Nemcsak az feltünő, hogy e tárgy folytonosan változik, hanem az is, hogy e tárgy valójában rendszer, amelynek mi magunk, élölények is részesei vagyunk. Ezért a környezetpolitika nem lehet statikus, az ökológiai válságból való kilábalásra tett erőfeszítések csak folyamat- és rendszerszemléletben ragadhatók meg.

A környezetpolitika ma jellemző eszközei a következők: ${ }^{8}$

- piacorientált eszközök: környezeti adók, betétdíjak alkalmazása, támogatások, sajátos felelősségi szabályok alkalmazása;

- technológiai standardokat vagy gazdasági teljesítményt elöíró adminisztratív szabályozók;

- önszabályozás és kiszerződés;

- környezetvédelmi tájékoztatás (például ökocímkék, energiatanúsítványok alkalmazása).

A piacorientált eszközök és az adminisztratív szabályozók az adaptáció statikus felfogásán alapuló hagyományos eszközök, az önszabályozás és a tájékoztatás azonban olyan irányítási eszközök, amelyek a transzcendáló kommunikáció, a mentális reakció és a kreáció lehetőségeire is figyelemmel vannak.

5 EKINS: i. m., 6.

6 CAPRA: i. m., 157.

7 CAPRA: i. m., 168.

8 EKINS: i. m., 8-9. 
Naivitás azt képzelni, hogy a gazdasági teljesitmény pénzben mérhető növekedése feltétlenül hozzájárul az emberi jólét növekedéséhez. Ha a gazdasági növekedés együtt jár az erőforrások kimerítésével, továbbá növeli a szennyezést és az üvegházhatást, akkor a jövedelem növekedésének jótékony hatását ellentételezik az elszenvedett környezeti károk. A növekedéssel szembeni óvatosság nemcsak a kapcsolódó környezeti károk miatt indokolt, hanem azért is, mert a környezeti hatásoktól függetlenül nem igazolható a pozitív összefüggés a gazdasági növekedés és az emberi jólét növekedése között. ${ }^{9}$

\section{A környezeti adóreform}

\subsection{A környezeti adóreform elvi kérdései}

A környezeti adók bevezetésével járó reform abban valósul meg, hogy az állami költségvetés számára bevétel teremthető elő a természeti erőforrások használatának és a környezeti szennyezésnek a megadóztatásával, továbbá környezeti javulás érhető el azáltal, hogy az erőforrások felhasználásának produktivitása javul. ${ }^{10} \mathrm{~A}$ környezeti adóreform váltásnak tekinthető a munkával előállítható, továbbá a tőkejavak (goods) adóztatásáról a környezeti veszélyek és terhek (bads) adóztatására, miközben az adóztatás intenzitása (a megtermelt jövedelem központosítása) nem növekszik, vagyis az adóztatási színvonal szempontjából a környezeti adóreform semleges.

Egy környezeti adóreform lehetséges hatásai a következőkben foglalhatók össze: ${ }^{11}$

- mivel a munkát és tőkét terhelő adók negatív ösztönzők, ezek eltávolítása hozzájárul a gazdasági növekedéshez, a környezeti adók alkalmazása viszont árdrágító hatással jár, ami a növekedésre negatív hatással van, és a kétféle hatás összevetéséböl lehet arra következtetni, hogy az egyébként semleges környezeti adóreform végső soron pozitív vagy negatív módon hat-e a gazdasági növekedésre;

- a munkát terhelö adó csökkentése hozzájárulhat munkaalkalmak megteremtéséhez, mivel az adócsökkentés következtében megnőhet a munkaerő iránti kereslet;

- a tőke és munka adóterheinek csökkentése ösztönözheti a technikai fejlődést és a technológiai innovációt.

Az ökológiai válság körülményei között a piaci önszabályozás mechanizmusai bizonyos tekintetben felfüggesztődnek, még ha az egyes vállalkozások menedzserei erröl sokszor nem is vesznek tudomást. A válság elsődleges oka az, hogy az egyre szükösebben rendelkezésre álló természeti erőforrások nem termelhetők újra, és a természeti környezet regenerációs képességének csökkentése is egyre növekvő terhet rak a társadalomra, ennek következtében pedig nem lehet megakadályozni monopóliumok kialakulását. Az állami beavatkozás lehetséges indoka általában az,

9 EKINS: i. m., 9.

10 EKINS: i. m., 14-15.

11 EKINS: i. m., 14-15. 
hogy kívánatos a meg nem szolgált - például monopolhelyzeteknek betudható nyereség vagy egyébként nem ellentételezett vagyoni előny elvonása. Mivel a rendkívüli nyereség nem tudható be a versenygazdaság szokásos körülményei között elérhető eredménynek, elvonása nem is tekinthető versenytorzítónak.

Az állam az elvonással vagy közvetlen adminisztratív beavatkozással befolyást kíván gyakorolni az érintettek magatartására. Például monopóliumokkal szembeni hozzáférést biztosít, vagy indokolt lehet takarékos bánásmódra késztetés a szükösen rendelkezésre álló, a környezetre nagy tehertételt jelentő javakkal (például ilyen a fosszilis energia). A beavatkozás kívánatos célja lehet nemcsak az ökológiai válság, hanem más egyensúlyi probléma is. Ilyen például a pénzügyi hiperaktivitás visszaszorítása, amely ugyanis a pénzügyi piacok számára rendszerszintű kockázatot hordoz. Lehetséges továbbá rendkívüli vagyoni előny elvonása akár konfiskáló hatású adóval is (például a csődbe ment bankok által kifizetett felső vezetői jutalmak esetén).

Az állami beavatkozás fent leírt eszközei ún. Pigou-adók, ${ }^{12}$ vagyis céljuk túltermelés vagy hiperaktivitás megakadályozása, amelyhez olyan tevékenység vezet, aminek a gyakorlása túlzott tehertétel a társadalom számára; és az adóztatással történő beavatkozás a költségek egy részét áthárítja azok okozójára, fékezve ezzel a nem kívánt aktivitást. A környezetszennyező tevékenység vagy a tőkepiacokon tapasztalt hiperaktivitás visszafogása például közérdek. Az alkalmazandó adómérték az adóztatandó tevékenység által kiváltott többletteher és nulla közötti értékre vetíthetö.

A környezetvédelmi adó parafiskális eszköz, mert a bevételszerzés másodlagos a magatartásszabályozáshoz képest. A környezeti adók esetében szűk értelemben véve elégséges ugyan hivatkozni arra, hogy ez esetben a gazdasági magatartás környezetre gyakorolt negatív hatását kell adóztatni, ha azonban tágabb összefüggésben gondolkodunk, akkor parafiskális irányítási eszközökre, vagyis korrektív adókra kell utalnunk, és ez esetben a fogalomba bele kell foglalni a gazdasági magatartás környezetre nézve kedvező befolyásolásának célját is. ${ }^{13}$ Ehhez képest a nemzetközi szervezetekre az jellemző, hogy a múlt század '90-es éveitől fogva lényegében máig a szük megközelítést részesítik előnyben, és a kiváltott hatásra összpontosítanak. Ez összefügg azzal, hogy a környezeti adók feltünhetnek versenytorzító intézkedésként, ami viszont az alapvető EU-szabadságokkal nem egyeztethető össze. ${ }^{14}$

Mivel, amit tág összefüggésben környezeti adónak hívunk, gyakran nem adó, hanem olyan közteher, amelynek teljesítése ellenértékeként igénybe vehetők közössé-

12 PIgou, Arthur C.: The Economics of Welfare. Macmillan, London, 1932, Part II, Chapter IX: Divergences Between Marginal Social Net Product and Marginal Private Net Product.

13 Pitrone, Federica: Defining „Environmental Taxes”: Input from the Court of Justice of the European Union. Bulletin for International Taxation, 2015/69, 61.

14 „The EU and the OECD working group defined as 'environmental' a tax whose: tax base is a physical unit (or a proxy of it) of something that has a proven, specific negative impact on the environment, when used or released.” [Az Európai Unió és az OECD munkacsoportjai által meghatározott „környezeti” adó fogalma a következő: olyan adó, amelynek adóalapjaként a dolog egy meghatározott fizikai egysége (vagy annak egy összetevője) szolgál, melynek használata vagy kibocsátása bizonyítottan negatív hatást gyakorol a környezetre. - a szerk.] PITRone: i. m., 59; European Commission: Manual: Statistics on Environmental Taxes, Brussels, 1996, 7. és 3. szakasz; Eurostat: Environmental Taxes; A Statistical Guide, Brussels, 2013, 8-9. 
gileg szervezett szolgáltatások, e tekintetben lehetséges tárgyalni az adó, a bírság és az illeték fogalmait is. ${ }^{15} \mathrm{Az}$ adót köztestület közcélból írja elő törvényes eszközökkel. A bírság olyan fizetési kötelezettség, amelynek a kivetését magatartásszabályozó elöírás megszegése előzi meg. Az illeték közszolgáltatásért fizetett ellenérték, amely a szolgáltatás költségeinek fedezésére szolgál, az adófizetéshez pedig olyan előny kapcsolódik, amely általában nem arányos a szolgáltatás értékével.

A környezeti adók alkalmazására irányuló fiskális politika fontos eszköze az adókedvezmények célzott alkalmazása. Az állami támogatás többnyire káros a környezetre. A támogatás eltorzítja az árakat és az erőforrások költséghatékony elosztását, ami káros a gazdaságra és a természeti környezetre is. Példák: a fosszilis energiából nyert üzemanyag árának alacsonyan tartása hatósági eszközökkel, a közúti közlekedés vagy a vegyszeres mezőgazdasági termelés támogatása káros a környezetre. Ellenpéldák is vannak: kedvező ökológiai szempontból a biogazdák támogatása, bár az ilyen támogatások tényleges hatásainak a felmérése bizonytalan. ${ }^{16}$

A környezeti szempontból ártalmas állami támogatások kiküszöbölése a kötelezettségvállalások ellenére is csak lassan halad az Európai Unióban. ${ }^{17} \mathrm{~A}$ támogatáshoz kapcsolt célkitűzések általában nem problematikusak ökológiai szempontból, de a beavatkozás tervezése problematikus lehet. Így például gondot jelent, ha a szabályozásból hiányzik a beépített felülvizsgálati folyamat. A társadalmi hatások is lehetnek kedvezőtlenek. Például farmerek vagy halászok számára kedvező egy intézkedés, de a társadalom egésze számára nem, vagy például a bányászati támogatások egészségromláshoz vezethetnek, a nukleáris energiatermelés támogatása növeli a nukleáris baleset kockázatát stb. ${ }^{18} \mathrm{~A}$ gazdasági hatások iránya szerint a támogatások irányulhatnak a termelés vagy a fogyasztás befolyásolására, vagy számba vehetjük a kiesett adóbevétel gazdaságra gyakorolt hatását vagy a versenytorzító hatást. ${ }^{19}$

A közép- és kelet-európai tagállamok számára különösen fontos a regionális fejlesztés. A regionális támogatások alkalmazásáról szóló hivatalos EU-tájékoztató (Regional State Aid Guidelines) azonban egyáltalán nem tartalmaz környezetvédelmi megfontolásokat, ami súlyosan hat ki az amúgy sem fejlett, térségbeli országokra. ${ }^{20}$ Bár az EUMSZ ${ }^{21} 11$. cikke elöírja a környezetvédelmi szempontok figyelembe-

15 SnAPE, John-DE SouzA, Jeremy: Environmental Taxation Law. Policy, Contexts and Practice. Ashgate, Aldershot, Burlington, VT, 2006, 5-6.

16 OECD, Environmentally Harmful Subsidies. Challenges for Reform. Paris, 2005, 7.

17 Withana, Sirini-ten Brink, Patrick-Franckx, Laurent-Hirschnitz-Garbers, Martin-Mayeres, Inge-Oosterhuis, Frans-PoRsCH, Lucas: Study Supporting the Phasing Out of Environmentally Harmful Subsidies. A report by the Institute for European Environmental Policy, Institute for Environmental Studies - Vrije Universiteit, Ecologic Institute and Vision on Technology for the European Commission - DG Environment; Final Report, Brussels, 2012, i.

18 Withana és társai: i. m., iii.

19 Withana és társai: i. m., iv.

20 Bennink, Dorien-Faber, Jasper-Smit, Martine-Goba, Vineta-Miller, Karen-Williams, Evan: Integrating Resource Efficiency and EU State Aid. An Evaluation of Resource Efficiency Considerations in the Current EU State Aid Framework. AEA Technology plc, Final Report for the European Commission, Brussels, 2012, iv.

21 Az Európai Unió müködéséröl szóló szerződés egységes szerkezetbe foglalt változata, HL C 115, 2008. 05. 09., 47. 
vételét az egyes uniós politikák megvalósításánál, e követelmény a valóságban nem teljesül. ${ }^{22}$

Természeti erőforrásokat terhelő adókat korábban is alkalmaztak már, de a zöld adók csak akkor jelentek meg, amikor a közteher kivetéséhez kifejezetten (ha nem is kizárólagosan) környezetvédelmi célok kapcsolódtak. ${ }^{23}$ Fontos a mikroökonómiai megközelítés, amelynek képviselői az adókivetést követő jóléti maximalizálás lehetőségét kutatják, egyensúlyt keresve nemcsak általában az adóbevétel és az adott termelésre az adóztatással rárakódó ráfordítás között, hanem a negatív externáliák megszüntetése és az adott termelésre az adóztatással rárakódó ráfordítás között is. ${ }^{24}$ Egy újabb megközelítés makroökonómiai alapon nyugszik. Ebben az esetben arra összpontosítunk, hogy nemcsak a környezetszennyezés csökkenthetö, hanem az adómix átrendezésével lehetséges felszabadítani olyan terheket, amelyek jelenleg a munkára, a tőkére és az értékesítésekre rakódnak rá (double dividend).

Racionális piaci szereplőket feltételezve, optimalizációt keresve a kibocsátás és ezzel együtt a környezetkárosítás - csökkentése mint elöny, és a csökkentés érdekében vállalt terhek (szabályozási költség) között, elméletileg lehetséges találni olyan állapotot, amelyben a szennyezés csökkenéséböl származó társadalmi haszon meghaladja a szabályozási költségeket, ami viszont igazolja a beavatkozás jogosságát. ${ }^{25} \mathrm{~A}$ közgazdasági és ökológiai nézőpontok mindenesetre különböznek egymástól, mert közgazdasági szempontból az optimális kibocsátás (ami terhet is jelent a környezetre) nem nulla, hanem pozitív érték, ökológiai szempontból azonban nulla, ez utóbbi esetben viszont az enyhítési költségek - mert adottak - meghaladják a károk csökkentésével elérhető előnyt. Döntő érv a környezetpolitika igazolása mellett az, hogy az önszabályozó piac intézményrendszerének fenntartása nem nélkülözheti a gazdaságon kívüli beavatkozást, ami viszont tranzakciós és egyéb terhet rak a társadalomra, amit akkor is meg kell fizetni, ha nincs kibocsátás. ${ }^{26}$

\subsection{Európai tendenciák a környezeti adópolitikában}

Az Európai Környezeti Ügynökség (European Environment Agency, EEA) elemzéséből az alábbiakra lehet következtetni: ${ }^{27}$

- a föbb beavatkozási területek a következök: energiafelhasználás, az üvegházhatást előidéző kibocsátás megfékezése, vízhasználat, hulladékkezelés, a közlekedés és szállítás környezeti terheinek (légszennyezés, zajártalom) csökkentése;

- piackonform beavatkozási eszközök: adminisztratív szabályozás (i), adópolitika (ii), engedélyek, kvóták és tanúsítványok kibocsátási rendjének előírása (iii),

22 BenNink és társai: i. m., v.

23 Markandya, Anil: Environmental Taxation: What Have We Learnt in the Last 30 Years? In: Castellucci, LauraMarkandya, Anil (eds.): Environmental Taxes and Fiscal Reform. Palgrave, Basingstoke, New York, NY, 2012, 10.

24 MarkandYa: i. m., 10.

25 Markandya: i. m., 13.

26 MaRKANDYA: i. m., 14.

27 SPECK, Stefan-PALEARI, Susanna: Environmental Taxation and EU Environmental Policies. European Environment Agency Report No 17/2016. Publications Office of the European Union, Luxembourg, 2016, 5. 
használati díjak kivetése (iv), a termelők felelősségének szabályozása és a túlfogyasztás megállítása $(\mathrm{v})$;

- legelterjedtebb adónemek: energiaadók, karbonszármazékok adója, gépjármúadó, ugyancsak elterjedtek a hulladékkezelési díjak, kevésbé elterjedtek: lég- és vízszennyezés adóztatása és a természeti erőforrások használatának különadóztatása.

A 2016-os felmérés szerint 82 kötelező és 84 ajánlott célt fogalmaztak meg, továbbá 18 kötelező és 24 ajánlott beavatkozási eszközt vezettek be a tagállamokban. A beavatkozásnak EU-szinten kilenc kijelölt területe van: ${ }^{28}$

- energiafelhasználás;

- üvegházhatást és ózonlyukat előidéző anyagok kibocsátásának korlátozása;

- légszennyezés;

- közlekedésszabályozás (károsanyag-kibocsátás és zajterhelés csökkentése);

- hulladékkezelés;

- ökológiai vízgazdálkodás;

- fenntartható fogyasztás és termelés szabályozása;

- vegyi anyagokkal való óvatos bánásmód;

- biodiverzitás és ökológiai földhasználat.

Az adók alkalmazásának ${ }^{29}$ fö célja a szennyezés és a természeti erőforrások túlzott használatának csökkentése; másodlagos céljai a népegészségügyi helyzet javítása, munkaalkalom teremtése, hozzájárulás a fenntartható termeléshez és fogyasztáshoz.

Az energiaadó az energiafogyasztás visszafogását célozza, a karbonadó viszont a karbonszármazékok felhasználásától kívánja az adózókat visszariasztani. Az Európai Bizottság 2011-ben javasolta az energiaadó átalakítását karbonadóvá oly módon, hogy az adót nem a felhasznált energia mennyisége, hanem karbontartalma alapján kellett volna megfizetni, ${ }^{30}$ de a Bizottság 2015-ben kénytelen volt javaslatát visszavonni, miután nem tudta megszerezni az Európai Tanács támogatását. ${ }^{31}$

A gyakorlatban Európában három nagy kategóriára oszthatók a környezeti adók: energiaadó (amelyre harmonizáló irányelv is van), a közlekedést terhelő adók és a hulladékgazdálkodásra irányuló adók. ${ }^{32}$ Mivel az elkövetkező években, a 2051-ig tartó időszakban várható az üvegházhatást kiváltó anyagok jelentős csökkenése és az elektromos autók elterjedése, nem várható a zöld adókból származó bevételek

28 SPECK-PALEARI: i. m., 7.

29 SPeCK-PAleari: i. m., 5.

30 Lásd az Európai Bizottság IP/11/468. számú javaslatát. http://europa.eu/rapid/press-release_IP-11-468_ hu.htm (2017. 01. 10.).

31 Lásd Taxation Trends in the European Union. Data for the EU Member States, Iceland and Norway. Luxembourg, Publications Office of the European Union, 2016, 27-28. http://ec.europa.eu/taxation_customs/ sites/taxation/files/resources/documents/taxation/gen_info/economic_analysis/tax_structures/2016/econ_ analysis_report_2016.pdf (2017.01. 10.).

32 Taxation Trends in the European Union, i. m., 34. 
emelkedése, sőt inkább várhatóan ezek csökkenése következik be. ${ }^{33} \mathrm{~A}$ közeljövőben sajnos általános költségvetési feszültségek várhatók, mivel a zöld adók jelentőségének csökkenése mellett számolni kell a foglalkoztatottság csökkenése és az elöregedésből származó magasabb szociális kiadások miatt bekövetkező adóbevétel-csökkenéssel is. ${ }^{34}$

\section{Az Európai Unió Bíróságának gyakorlata}

Az EU keretei között megvalósított környezeti adóharmonizáció szerény eredményeket mutat fel, és csupán részlegesnek tekinthető. Az egyetlen szük értelemben vett környezeti adóharmonizációs intézkedés az energiaadó-irányelv. ${ }^{35} \mathrm{Az}$ irányelv a kötelezően alkalmazandó minimum adómértékeket igen alacsony szintben állapítja meg, továbbá az intenzív energiafelhasználókat széles körben mentesíti az adózás alól. Az egyszerü termékmennyiség helyett a karbontartalom alapján történő adóztatás sokat javított volna a helyzeten, az irányelv-módosítási javaslat azonban a Bizottság sikertelen kísérletének bizonyult. A fentiekből az a következtetés vonható le, hogy az energiaadó-irányelv ténylegesen csak részben szolgál környezetpolitikai célokat. ${ }^{36}$

Közvetlen jelentősége van még ökológiai szempontból a jövedéki adók harmonizációjának. Kiemelendő e körben az ún. horizontális irányelv. ${ }^{37}$ További kérdés a környezetvédelmi célú adókedvezmények közösségi joggal való összeegyeztethetőségének problémája. Az erre irányuló tagállami intézkedések állami támogatásnak minősülhetnek, ami tilos, illetve a Bizottság által engedélyeztetendő.

\subsection{A harmonizációs irányelveknek való megfelelés kérdése}

A Braathens-ügyben ${ }^{38}$ az Európai Unió Bírósága megállapította, hogy a tagállami adó nem egyeztethetö össze a 92/12/EGK (horizontális) irányelvvel, és az ásványolajtermékek harmonizált jövedéki adózásáról szóló 92/81/EGK irányelvvel sem. Abban a kérdésben kellett dönteni, hogy vajon a tagállami adóztatás az üzemanyagfogyasztásra irányul-e vagy pedig a szennyező szénhidrogén-kibocsátásra. A svéd kormány álláspontja szerint az üzemanyag-fogyasztás csak azért kerül szóba, mert

33 Taxation Trends in the European Union, i. m., 38.

34 Taxation Trends in the European Union, i. m., 39-40.

35 Lásd az Európai Unió Tanácsának 2003/96/EK irányelvét (2003. 10. 27.) az energiatermékek és a villamosenergia közösségi adóztatási keretének átszervezéséről. HL L 283, 2003. 10. 31., 51.

36 Lásd az Európai Unió Tanácsának 2003/96/EK irányelvét (2003. 10. 27.) az energiatermékek és a villamosenergia közösségi adóztatási keretének átszervezéséröl. HL L 283, 2003. 10. 31., 51. elberg, 2016 , 207.

37 Lásd az Európai Unió Tanácsának 2008/118/EK irányelvét (2008. 12. 16.) a jövedéki adóra vonatkozó általános rendelkezésekről és a 92/12/EGK irányelv hatályon kívül helyezéséről. HL L 9, 2009. 01. 14., 12.

38 C-346/97. sz., Braathens Sverige AB kontra Riksskatteverket ügyben 1999. június 10-én hozott ítélet (ECLI:C:1999:291). 
a szennyezőanyag-kibocsátást az adókötelezettség megállapítása szempontjából annak alapján lehet mérni, hogy az adózónak mekkora az üzemanyag-fogyasztása (18-19. pont). Az Európai Unió Bírósága ezzel szemben azt állapította meg, hogy az üzemanyag-fogyasztás és a szennyezöanyag-kibocsátás között szétválaszthatatlanul szoros összefüggés van, ezért a tagállami adó a harmonizációs irányelvek hatálya alá tartozik (23. pont). Miután pedig a tagállami adó a horizontális irányelv hatálya alá tartozik, figyelembe kell venni az ásványi olaj irányelv 8 . cikkébe foglalt rendelkezést is, miszerint az adózás alól mentesíteni kell az üzemanyag felhasználását, ha azt nem magáncélú légi közlekedésben használják fel (26. pont). Amint látható, adott esetben a harmonizációs irányelv keresztezte a környezetvédelmi megfontolást, és megakadályozta a tagállamot környezetvédelmi politikájának érvényesítésében.

A Transportes Jordi Besora ügyben ${ }^{39}$ világossá válik, hogy a bírósági gyakorlatban a környezeti adó olyan környezetjogi eszköz, amelyet nem csupán célja vagy tárgya, hanem mindenekelött hatása alapján minősíthetünk környezeti adónak. Az ítélet 36. bekezdéséből kitünik, hogy a tagállami adó nem egyeztethető össze a horizontális jövedéki adózási irányelvvel, mert nincs olyan jól meghatározott szakpolitikai célja, amely az egyszerü költségvetési megfontolásoktól világosan megkülönböztetné. ${ }^{40}$

Egy tagállami adó akkor tekinthető összeegyeztethetőnek a horizontális jövedékiadó-irányelvvel, ha specifikus, ami azt jelenti, hogy olyan célra kell irányulnia, amely különbözik a költségvetési bevétel megszerzésének egyszerű céljától. Esetünkben ilyen cél az egészségügyi vagy környezetvédelmi kiadások fedezése, a kérdéses adó azonban nincs közvetlenül összekötve a megadóztatott ásványolajtermék felhasználásával. Az adóbevételt ugyan az autonóm tartomány általános egészségügyi vagy környezetvédelmi célokra fordíthatja, miután a központ azt visszautalta, de az ásványolaj felhasználásának megadóztatása nem irányul közvetlenül az olyan károk, illetve terhek enyhítésére, amelyek az ásványolaj felhasználásával függenek össze, vagyis az adó maga végső soron nem arra irányul, hogy visszatartsa az ásványolaj felhasználóit a megadóztatott termék felhasználásától (30-32. pontok).

A vizsgált adót akkor tekinthetnénk az irányelv 3. cikk (2) bekezdése értelmében specifikusnak - vagyis különleges célú adónak -, ha parafiskális eszköz, vagyis korrektív adó lenne, abban az értelemben, hogy az elsődleges cél nem a költségvetési bevétel elérése, hanem a társadalom számára terhet jelentő, illetve károsnak tekinthető magatartás visszaszorítása. Jellemző a parafiskális eszköz esetében az is, hogy ilyenkor az állam közszolgáltatások formájában ellenszolgáltatást nyújt. Például hozhat környezetjavító intézkedéseket vagy elvégezhet környezetvédelmi beruházásokat. Elmondható továbbá, hogy az adóbevétel felhasználása rendszerint az állami költségvetésen belül külön alapba kerül. Mivel a jogvita tárgyát képező tagállami adó nem volt eléggé célzott, nem volt a tagállam számára megengedhető a harmonizált jövedéki adózáson túl külön környezeti adó bevezetése.

39 C-82/12. Sz., Transportes Jordi Besora SL kontra Generalitat de Catalunya ügyben 2014. február 27-én hozott ítélet (ECLI:C:2014:108).

40 Pitrone: i. m., 63. 
Szintén a különleges cél fogalma alá való besorolhatóság volt vitás a Statoil Fuel, Retail Eesti ügyben.$^{41} \mathrm{Az}$ Európai Unió Bíróságának a folyékony tüzelőanyag kiskereskedelmi értékesítésére kivetett tagállami adó esetében abban kellett állást foglalnia, hogy az vajon eléggé speciális-e ahhoz, hogy elkerülje a harmonizált jövedéki adóztatás hatályát. Az adó különleges célja, és így környezetvédelmi adó megállapíthatósága mellett azzal lehet érvelni, hogy az adót a tömegközlekedés elősegítése és következésképpen a közúti forgalom és annak a környezetre gyakorolt negatív hatásának a csökkentése céljából szedik be. További érvként említhető, hogy „az említett adó célja olyan termékek fogyasztásának és szolgáltatások igénybevételének a szankcionálása, amelyek alkalmasak arra, hogy szociális kiadásokat keletkeztessenek vagy negatív külső hatásokat idézzenek elö" (25. pont).

Mivel a magatartás befolyásolása mellett a parafiskális eszköz másik tulajdonsága, hogy összefüggést teremt a befizetés és a közösségi szolgáltatás megszervezése között, az is vitatott kérdéssé válik a konkrét ügyben, hogy ténylegesen mire fordítják az adóbevételt. Érvelhetünk azzal, hogy az „olyan adónak, mint amelyről az alapügyben szó van - annyiban, amennyiben a jövedékiadó-köteles folyékony tüzelöanyag kiskereskedelmi értékesitését súitja -, különleges célja van, ha a tömegközlekedésnek az adót elöiró önkormányzat területén történő müködtetésének a finanszírozására irányul, és az ezen adóból származó bevételeket kizárólag e tevékenység megvalósitása céljából használják fel", abban az esetben is, ha ezen önkormányzatnak az említett adó fennállásától függetlenül is kötelessége e tevékenység ellátása és finanszírozása (32. pont). A Transportes Jordi Besora ügyhöz hasonlóan irányadó ebben az esetben is, hogy különleges célként csak a tisztán költségvetési céloktól eltérő cél fogadható el (37. pont).

A Fendt-ügyben ${ }^{42}$ hozott bírósági döntés jelentősége abban áll, hogy a tagállam nem feltétlenül korlátozható a harmonizációs irányelvek által adóztató hatalmának gyakorlásában. A Fendt-ügyben hozott ítélet lényegi állítása, hogy nem korlátozható a tagállam azon joga, hogy a nem tüzelöként, fütő- vagy üzemanyagként felhasznált kenőolajokat terhelő adót írjon elő. A vonatkozó irányelvek hatálya ugyanis pontosan behatárolt. $E$ tekintetben tehát akadálytalanul érvényesülhet a tagállam környezetvédelmi politikája.

„A 2003/96/EK irányelvet úgy kell értelmezni, hogy az nem tiltja az olyan nemzeti szabályozást, amely a kenőolajokat sújtó adót ír elö, amennyiben ezeket nem tüzelö-, fütő- vagy üzemanyagként való felhasználásra szánják, illetve nem ekként kínálják eladásra vagy felhasználásra. Ugyanis, még ha a nem tüzelö-, fütö- vagy üzemanyagként felhasznált kenőolajok az irányelv 2. cikke (1) bekezdésének b) pontja szerinti „energiatermékek” fogalmába tartoznak is, ezeket ugyanezen irányelv ugyanezen cikke (4) bekezdése b) pontjának első francia bekezdése kifejezetten kizárja az irányelv hatálya alól, következésképpen e termékek nem tartoznak a harmonizált jövedéki adó rendszerébe. E körülményekre figyelemmel meg kell állapítani

41 C-553/13. sz., Tallinna Ettevõtlusamet kontra Statoil Fuel \& Retail Eesti AS ügyben 2015. március 5-én hozott ítélet (ECLI:C:2015:149).

42 C-145/06. és C-146/06. sz., Fendt Italiana Srl kontra Agenzia Dogane - Ufficio Dogane di Trento egyesített ügyekben 2007. július 5-én hozott ítélet (ECLI:C:2007:411). 
azt is, hogy a hivatkozott kenőolajok nem minősülnek a jövedékiadó-köteles termékekre vonatkozó általános rendelkezésekről és e termékek tartásáról, szállításáról és ellenőrzéséről szóló 92/12/EGK irányelv 3. cikke (1) bekezdésének első francia bekezdésében felsorolt termékeknek sem. Ily módon az e cikk (3) bekezdése elsö albekezdésének megfelelően a tagállamok fenntarthatják az arra vonatkozó jogot, hogy adókat vezessenek be vagy tartsanak fenn e termékekre is, amennyiben ezen adók nem eredményeznek határátlépési formaságokat a tagállamok közötti kereskedelemben (43-44. pontok)." A jövőre nézve nincs jelentősége, hogy az ügyben szereplő vonatkozó jövedéki adózási irányelveket azóta újabbakkal váltották fel.

A Flughafen Köln ügyben ${ }^{43}$ az volt az eldöntendő kérdés, hogy az adózó hivatkozhat-e a harmonizált energiaadó-irányelvbe foglalt mentességre, ha egy tagállam csak késéssel vezet be adót az adózott gázolaj villamosenergia-elóállításra való felhasználására. Az ügyben szereplő fél, az adózó a repülőgépek fedélzeti villamosenergia-ellátásának biztosítására földi villamosenergia-előálító aggregátorokat müködtet. A tagállam megadóztatja a gázolaj villamosenergia-elóállításra való felhasználását, fölmerült azonban a kérdés, hogy ez nem ütközik-e a harmonizált energiadó-irányelv mentesítésről szóló 14. cikkének rendelkezéseibe. Az a körülmény, hogy a 14. cikk (1) bekezdése bevezető fordulatában mérlegelési lehetöséget tart fenn a tagállamok számára a kivétel megfelelő és egyszerủ alkalmazásának biztosítására irányuló feltételek tekintetében, nem kérdőjelezi meg a hivatkozott mentesítési kötelezettség feltétlen jellegét. Mivel pedig a villamosenergia előállításához felhasznált energiatermékeknek a „szóban forgó irányelvben előírt adó alóli mentesítésére irányuló kötelezettség megfogalmazása kellóen pontos és feltétlen, biztositott a magánszemélyek számára azon jog, hogy az összeegyeztethetetlen nemzeti szabályozással szemben az irányelv kivételes szabályára hivatkozzanak a tagállami bíróság elött" (32-33. pontok).

A Plantanol-ügy ${ }^{44}$ tárgya az volt, hogy a tagállami intézkedés összeegyeztethető-e a bioüzemanyagok használatának előmozdításáról szóló (azóta hatályon kívül helyezett) irányelvvel, továbbá a harmonizált energiaadó-irányelvvel. „A közlekedési ágazatban a bioüzemanyagok, illetve más megújuló üzemanyagok használatának előmozdításáról szóló 2003/30 irányel\5 3. cikkét úgy kell értelmezni, hogy azzal nem ellentétes az olyan nemzeti szabályozás, amely az általa a bioüzemanyagok javára elöírt adómentességi rendszerböl kizárja a növényi olaj, fosszilis dízelüzemanyag és különleges adalékanyagok keverékéből nyert terméket. Egyrészt ugyanis ezen irányelv (19) bekezdéséböl kitünik, hogy bár az adómentességi rendszer az említett irányelvben elöírt célok eléréséhez a tagállamok rendelkezésére álló eszkö-

${ }^{43}$ C-226/07. sz., Flughafen Köln/Bonn GmbH kontra Hauptzollamt Köln ügyben 2008. július 17-én hozott ítélet (EU:C: 2008:429).

44 C-201/08. sz., Plantanol GmbH \& Co. KG kontra Hauptzollamt Darmstadt ügyben 2009. szeptember 10-én hozott ítélet (EU:C:2009:539), 36-37. pont.

45 Lásd az Európai Parlament és a Tanács 2003/30/EK irányelvét (2003. május 8.) a közlekedési ágazatban a bioüzemanyagok, illetve más megújuló üzemanyagok használatának előmozdításáról. HL L 123, 2003. 05.17. 42. Ezt hatályon kívül helyezte az Európai Parlament és a Tanács 2009/28/EK irányelve (2009. április 23.) a megújuló energiaforrásból elóállított energia támogatásáról, valamint a 2001/77/EK és a 2003/30/EK irányelv módosításáról és azt követő hatályon kívül helyezéséröl. HL L 140, 2009. 06. $05 ., 16$. 
zök egyike, más olyan eszközök is elképzelhetök, mint a feldolgozóiparnak nyújtott pénzügyi támogatások vagy az olajtársaságok számára kötelező bioüzemanyaghányad elöírása. Másrészt a 2003/30 irányelv 3. cikkének (4) bekezdéséből kiolvasható, hogy a tagállamok széles mérlegelési jogkörrel rendelkeznek az irányelv által elöirt célok elérése érdekében támogatandó termékeket illetően, így az említett államok a támogatásnál elsőbbséget biztosíthatnak bizonyos típusú üzemanyagoknak, figyelembe véve azok teljes éghajlati és környezeti mérlegét, jövedelmezőségét, csakúgy, mint a versenyképességet és az ellátási biztonságot."

$\mathrm{Az} I R C C S$-ügy ${ }^{46}$ tárgyát a villamosenergia-rendszer általános költségeinek fedezeteként fizetendő dijak képezik, illetve az a kérdés, hogy a költség-visszatérítés nem minősül-e állami támogatásnak, ami a közösségi jog értelmében tilos. E díjakat az Európai Unió Bírósága adóként fogta fel, a költség-visszatérítést pedig adókedvezményként. A tagállami hatóságok megtagadták, hogy az adózó alapítvány igénybe vegye a tagállami villamosenergia-rendszer általános költségeinek fedezeteként fizetendő díjakkal kapcsolatos kedvezmények nemzeti rendszerét.

Megfigyelhető, hogy a harmonizált energiaadó-irányelv megadja a tagállamnak a differenciálás lehetőségét, amit a Bíróság sem vont kétségbe. Az irányelv (10) bekezdése azt írja elő, hogy a tagállamok különféle típusú adózást vezethetnek be, illetve tarthatnak fenn az energiatermékekre és a villamos energiára vonatkozóan. E célból a tagállamoknak meg kell engedni, hogy a minimum közösségi adómértékeknek úgy feleljenek meg, hogy figyelembe veszik a teljes kivetett adóterhet az összes olyan közvetett adó tekintetében, amelynek alkalmazása mellett döntenek (a hozzáadottérték-adó kivételével).

Az elözetes döntéshozatalra utaló határozatból az következik, hogy az alapügyben szóban forgó nemzeti szabályozás alapján kizárólag a feldolgozóágazatba tartozó, úgynevezett „nagy energiaigényü” vállalkozások részesülnek olyan kedvezményekben, amelyek a villamosenergia-rendszer általános költségeinek fedezeteként fizetendő díjakra vonatkoznak. „A 2003/96/EK irányelv 17. cikke (1) bekezdésének a) pontja értelmében a tagállamok a villamosenergia-fogyasztásra vonatkozó adókedvezményeket alkalmazhatnak a nagy energiaintenzitású vállalkozások javára, feltéve, hogy az ezen irányelvben elöírt uniós minimum-adómértékeket átlagosan minden üzleti vállalkozás tekintetében betartják. E rendelkezés meghatározza továbbá a „nagy energiaintenzitású vállalkozás” fogalmát, e meghatározás keretében pedig pontosítja, hogy a tagállamok szigorúbb fogalmat is alkalmazhatnak, beleértve az eladási érték, folyamat és ágazat meghatározásait. Ebböl következően az említett rendelkezés szerint a tagállamok a nagy energiaintenzitású vállalkozások javára nyújtott adókedvezmények igénybevételét továbbra is korlátozhatják egy vagy több ipari ágazat vállalkozásaira.

Következésképpen ugyanezen rendelkezés nem ellentétes az alapügyben szóban forgó olyan nemzeti szabályozással, amely kizárólag a feldolgozóágazat részére nyújt a villamosenergia-rendszer általános költségeinek fedezeteként fizetendő dijakra vonatkozó kedvezményeket. Ezen értelmezést a 2003/96/EK irányelv által

46 C-189/15. sz., Istituto di Ricovero e Cura a Carattere Scientifico (IRCCS) - Fondazione Santa Lucia kontra Cassa conguaglio per il settore elettrico and Others ügyben 2017. január 18-án hozott ítélet (ECLI: C:2017:17). 
követett célok vizsgálata is alátámasztja. Ugyanis ezen irányelv preambulumának (9) és (11) bekezdéséböl az következik, hogy az irányelv bizonyos mozgásteret hagy a tagállamok számára a nemzeti körülményekhez igazított politikák meghatározásához és végrehajtásához, valamint lényeges, hogy az említett irányelv végrehajtása keretében elfogadott intézkedésekröl az egyes tagállamoknak kell dönteniük (46-50. pontok)."

\subsection{Az alapvető szabadságokkal való összeegyeztethetöség}

Az Adria-Wien Pipeline, Wietersdorfer \& Peggauer Zementwerke ügyböl ${ }^{47}$ kitünik, hogy a gáz- és villamosenergia felhasználásának tagállami adóztatása alól az érintett tagállam mentességet biztosít a termék-előállítással foglalkozó vállalkozásoknak. A tagállam az adókedvezményt átfogó környezetpolitikai terv (Strukturanpassungsgesetz) keretében kívánta bevezetni, és a közterheket ennek megfelelően, objektív szempontok szerint kívánta elosztani. Az Európai Unió Bírósága nem fogadta el azt az érvet, hogy a termelővállalatok mennyiségben több energiát használnak fel, ezért rájuk az adóztatás miatt aránytalanul nagyobb teher hárul, hiszen az energiafogyasztás minden fogyasztó esetében a környezet terhelését eredményezi. Mivel tehát a tagállami adókedvezmény nem igazolható azzal, hogy az intézkedés az adórendszer általános szabályai közé lenne beilleszthető (the nature or general scheme of the taxation system), nem is fogadható el. A speciális adókedvezmény szelektív támogatásnak minősül (48-53. pontok).

A Frohnleiten-ügyben ${ }^{48}$ a határon átnyúló közvetett adó diszkriminatív jellege állapítható meg. Az ügyben először azt kellett tisztázni, hogy a hulladéklerakó üzemeltetője által fizetendő, a lerakott hulladék súlya és a hulladéklerakó állapota alapján kiszámított adó, amelyet csak akkor kell megfizetni, ha a hulladék a többi tagállamban fekvő szennyezett területekröl származik, vajon vámmal azonos hatású díjnak tekinthető-e, vagy hátrányos megkülönböztetéshez vezető belső adónak. A Bíróság az utóbbit állapította meg, tekintettel arra, hogy az adót nem a határátlépés tényéböl eredően szedik be (28. pont).

Mivel a határon átnyúló termékek adóztatása esetén termékadóról van szó, azt is tisztázni kellett, hogy a szóban forgó tagállami adó tényleg termékadó-e, amihez viszont az ártalmatlanításra szánt hulladékról kellett kimondani, hogy terméknek tekinthető. „Az ártalmatlanitásra szánt és sajátos kereskedelmi értékkel nem rendelkező hulladékok is - ártalmatlanitásukkal vagy lerakásukkal kapcsolatos - kereskedelmi ügylet tárgyát képezhetik. Az e hulladékokat terhelő belső adó megnehezítheti vagy költségesebbé teheti e kereskedelmi ügyleteket azon gazdasági szereplö számára, aki e hulladékokat át kívánja adni, és így alkalmas arra, hogy e hulladékok szabad mozgásának rejtett korlátozása legyen" (38. pont).

47 C-143/99. sz., Adria-Wien Pipeline GmbH and Wietersdorfer \& Peggauer Zementwerke GmbH kontra Finanzlandesdirektion für Kärnten ügyben 2001. november 8-án hozott ítélet (ECLI:C:2001:598).

48 C-221/06. sz., Stadtgemeinde Frohnleiten and Gemeindebetriebe Frohnleiten GmbH kontra Bundesminister für Land- und Forstwirtschaft, Umwelt und Wasserwirtschaft ügyben 2007. november 8-án hozott ítélet (ECLI:C:2007:657). 
Meg lehet állapítani azt is, hogy az olyan adó, mint az „Altlastenbeitrag”, amelynek esetében az adóköteles esemény az ártalmatlanításra szánt hulladék hulladéklerakóban való tartós lerakásának ténye, kizárólag azon kereskedelmi ügyletet terheli, amelynek - az ártalmatlanítással kapcsolatos ügyletektől eltekintve - e hulladék még a tárgyát képezheti, és hogy ami a többi tagállamból származó, ezen adó hatálya alá tartozó hulladékot illeti, azt csak ezen ügylet érdekében hozzák be az adókivető tagállamba. „Továbbá az olyan adó, amely nem a terméket mint olyant, hanem a vállalkozás termékkel kapcsolatos meghatározott tevékenységét terheli, és amelyet különösen a szóban forgó termék súlya alapján számolnak ki, az EK 90. (EUMSZ 110.) cikk hatálya alá tartozik, és amennyiben az adó azonnal megjelenik a belföldi és a behozott termék költségében, azt a behozott termékekre hátrányos megkülönböztetéstől mentesen kell alkalmazni” (41-43. pontok). Amint látható, a környezetvédelmi tagállami politika szétfeszíti a hagyományos kereteket, és a fogalom tág értelmezése révén lehetséges termékértékesítésként felfogni az ártalmatlanításra szánt hulladék lerakását és kezelését is.

„A hulladéklerakóban való tartós lerakás révén ártalmatlanításra szánt hulladékok - földrajzi származásuktól függetlenül - nyilvánvalóan hasonló termékek (59. pont). Ezért nemleges választ kell adni arra a kérdésre, hogy a belföldi hulladék és a többi tagállamból behozott hulladék közötti származásbeli különbség elegendő-e annak kizárására, hogy a hulladékok az EK 90. cikk értelmében hasonlóak legyenek (60. pont). Megállapítható viszont a hulladékok sajátos jellege azon tény alapján, hogy (a környezeti károk elsődlegesen a forrásuknál történő elhárításának elve értelmében, amely elv összhangban van a földrajzi közelség és az önellátás elvével) a hulladékokat a keletkezési helyükhöz lehetö legközelebb kell ártalmatlanítani annak érdekében, hogy szállitásukat a lehető legkisebb mértékre lehessen korlátozni. Ebből arra lehet következtetni, hogy figyelemmel a különböző helyeken keletkezett hulladékok közötti eltérésekre, valamint a hulladékok és a keletkezési helyük közötti kapcsolatra, az olyan nemzeti szabályozás, amely eltérően kezeli a belföldön keletkezett és a többi tagállamból származó hulladékokat, nem hátrányosan megkülönböztetö (61. pont). E megállapítás azonban kizárólag azon nem veszélyes hulladékokra vonatkozik, amelyekre nem terjed ki a veszélyes hulladékok országhatárokat átlépő szállitásának az Európai Közösségen belüli felügyeletéről és ellenőrzéséről szóló, 1984. december 6-i 84/631/EGK tanácsi irányelv9 hatálya (62. pont). Azon érvet illetően, miszerint a többi tagállam területén gyakorlatilag lehetetlen meghatározni a szennyezett vagy feltehetöen szennyezett területeket, emlékeztetni kell arra, hogy a gyakorlati nehézségek nem alkalmasak arra, hogy igazolják a hátrányosan megkülönböztető jellegü belső adók kivetését a másik tagállamokból származó árukra" (70. pont).

A British Aggregates Association ügyében ${ }^{50}$ „a Bíróság megállapította, hogy az állami beavatkozások által elérni kívánt cél nem elegendő ahhoz, hogy azok elkerüljék

49 A Tanács (EU) 84/631/EGK irányelve (1984. december 6.) a veszélyes hulladékok országhatárokat átlépő szállitásának az Európai Közösségen belüli felügyeletéröl és ellenőrzéséröl. HL L 326, 1984. 12. 13., 31.

50 C-487/06. sz., British Aggregates Association kontra Commission of the European Communities, United Kingdom of Great Britain and Northern Ireland ügyben 2008. december 22-én hozott ítélet (ECLI:C:2008:757). 
a közösségi jog értelmében vett 'támogatássá' minősítést. Ugyanis a közösségi jog nem tesz különbséget az állami intervenció okai vagy célkitüzései szerint, hanem azt annak hatásai alapján határozza meg" (84-85. pontok). Következésképpen nem elfogadható olyan álláspont, miszerint a tagállamok a különféle időszerü érdekek kiegyensúlyozásakor a környezetvédelem terén fennálló prioritásaik, és ebből következően, a környezetvédelmi adóval terhelni szándékozott termékek és szolgáltatások meghatározása terén korlátlan szabadsággal rendelkeznének.

Az a körülmény, hogy a sóderre vonatkozó tagállami környezetvédelmi adó nem alkalmazandó a környezetre hasonló hatással járó tevékenységek mindegyikére, lehetővé teszi annak megállapítását, hogy az ezen környezetvédelmi adó alól mentes, hasonló tevékenységek szelektív előnyben részesülnek. A Bíróság érvelése szerint az olyan megközelítés, amely kizárólag az elérni kívánt környezetvédelmi cél figyelembevételén alapul, nem elfogadható, mert „a priori kizárja annak a lehetőségét, hogy szelektív előnynek lehessen minősíteni annak hiányát, hogy az elérni kívánt cél tekintetében hasonló helyzetben lévő piaci szereplőket az adó személyi hatálya alá vonják, függetlenül a kérdéses adójogi intézkedés hatásaitól (86-87. pontok). Noha a környezetvédelem az EU egyik alapvető célja, a környezetvédelemmel kapcsolatos követelmények figyelembevételének szükségessége még akkor sem indokolja a szelektív jellegü intézkedések kizárását a versenyvédelmi szabályok hatálya alól, ha ezek olyan speciális intézkedések, mint a környezetvédelmi adók" (92. pont). ${ }^{51}$ Mivel az állami támogatások felöl nézve a jogalkotó céljaival nem igazolható a versenykorlátozó állami intézkedés, hanem ezzel szemben az állami beavatkozást annak tényleges hatása alapján kell megítélni, a környezetpolitikai szempontok értelemszerüen háttérbe szorulnak, és így a versenypolitikai megfontolások a környezeti és az adójogot egyaránt felülírják. ${ }^{52}$

A Kernkraftwerke Lippe-Ems ügyben ${ }^{53}$ a harmonizált energiaadó és a harmonizált jövedéki adó alkalmazhatóságával kapcsolatban is kérdés merült fel. További kérdés volt, hogy megkülönböztető tagállami adópolitika miatt nem valósult-e meg tiltott állami támogatás, és hogy vajon az Európai Atomenergia Közösséget létrehozó szerződés (Euratom Szerződés) alá tartozó hasadóanyag tekintetében nem lehetséges-e vámmal azonos hatású közteher kivetésének megállapítása, ami az uniós jog értelmében tilos. Az atomreaktort müködtető adózónak hasadóanyag-adót kell fizetnie. Az adózó kifogásolja, hogy a tagállami törvény érinti a különböző villamosenergia-termelők közötti versenyt azáltal, hogy a villamos energia atomerőmüvekben való előállításának adóztatását eredményezi. Ezzel szemben egyrészt a villamos energia előállításának más, olyan módjai, amelyek nem okoznak széndioxid-kibocsátást, másrészt pedig azon módjai, amelyek ilyen kibocsátásokat eredményeznek, nem adókötelesek.

51 Lásd még a kapcsolódó, T-354/04. sz., British Aggregates Association and Others v European Commission ügyben 2010. szeptember 9-én hozott ítéletet (ECLI:T:2010:366) és a folyamatban lévő T-741/15. sz., British Aggregates kontra Európai Bizottság ügyet, HL C 68. 2016. 02. 22., 38.

52 EzcurRa: i. m., 214-215.

53 C-5/14. sz., Kernkraftwerke Lippe-Ems GmbH kontra Hauptzollamt Osnabrück ügyben 2015. június 4-én hozott ítélet (ECLI:EU:C:2015:354). 
„A 2003/96/EK irányelv 2. cikkének (1) bekezdése meghatározza az „energiatermékek" ezen irányelv alkalmazásában vett fogalmát, (...) és kimeritő jelleggel állítja össze az e fogalommeghatározás alá tartozó termékek listáját" (47. pont). A Bíróság úgy ítélte meg, hogy az energiaadó-irányelv 14 . cikkében előírt mentességet nem lehet analógia útján alkalmazni a hasadóanyag-adóra, a hasadóanyag ugyanis nem energiatermék az irányelv értelmében véve (53. pont). „A Bíróság megállapította, hogy - a Braathens-ügytöl eltéröen - ez esetben nem áll fenn közvetlen és elválaszthatatlan kapcsolat a hasadóanyag felhasználása és az atomerömü reaktorában termelt villamos energia fogyasztása között" (65. pont). Ennek megfelelöen a kérdéses adó nem tartozhat a harmonizált jövedéki adók körébe sem, mert nem minősül sem jövedéki adónak, sem pedig egyéb közvetett adónak (66. pont).

„A hasadóanyagot felhasználó villamosenergia-termeléstöl eltérő villamosenergia-termelést nem érinti a tagállami hasadóanyag-adó törvényben létrehozott rendszer, és az e rendszerben kitüzött célra tekintettel e termelés semmiképpen nincsen hasonló ténybeli és jogi helyzetben a hasadóanyagot felhasználó villamosenergiatermeléssel, mivel egyedül ez utóbbi termelés során keletkeznek radioaktív hulladékok. Ebböl következik, hogy a vitatott tagállami adó nem minősül az EUMSZ 107. cikk (1) bekezdése értelmében vett szelektív intézkedésnek, és ezért nem minősül az e rendelkezésben tiltott állami támogatásnak" (79-80. pontok).

Az Euratom 93. cikk első bekezdését illetöen megjegyezhetö, hogy „e rendelkezés arra kötelezi a tagállamokat, hogy megszüntessenek egymás között minden behozatali és kiviteli vámot vagy azokkal azonos hatású díjat, továbbá a behozatalra, illetve a kivitelre vonatkozó minden mennyiségi korlátozást az Euratom Szerződés atomenergia közös piacára vonatkozó rendelkezéseinek hatálya alá tartozó áruk és termékek vonatkozásában. Azt kell tehát megvizsgálni, hogy a tagállam által bevezetett adó, amely nem minősül vámnak, vagy a behozatalra, illetve a kivitelre vonatkozó mennyiségi korlátozásnak, az e rendelkezés értelmében vett, vámmal azonos hatású díjnak minősül-e” (84-85. pontok). A Bíróság azt állapította meg, hogy a tagállami hasadóanyag-adót nem amiatt szedik be, hogy a hasadóanyag határt lép át, hanem a kereskedelmi célú villamosenergia-termeléshez történő felhasználása folytán, e fütőanyag származási helyének megkülönböztetése nélkül. A tagállami adótörvény ugyancsak nem tesz ilyen különbséget az adómérték, illetve az adófizetésre kötelezett személy tekintetében. Ebböl következik, hogy a tagállami adó nem minősül vámmal azonos hatású díjnak (91-92. pontok).

A T-251/11. sz., Osztrák Köztársaság kontra Európai Bizottság ügyben ${ }^{54}$ a jogvita tárgya, hogy a nagy villamosenergia-fogyasztó vállalatok számára a zöld villamos energiáról szóló osztrák törvény szerint nyújtott támogatás összeegyeztethetö-e az uniós joggal. A vita azért keletkezett, mert a tagállam által bejelentett támogatási projektet a Bizottság nem hagyta jóvá. A határozatot a tagállam a Törvényszék előtt megtámadta.

„Az EU Törvényszékének megállapitása szerint egy olyan nemzeti intézkedésnek az EUMSZ 107. cikk (1) bekezdése alapján való vizsgálatát illetően, amely azáltal

54 T-251/11. sz., Ausztria kontra Európai Bizottság ügyben 2014. december 11-én hozott itélet (ECLI: EU:T:2014:1060). 
kívánja ösztönözni a zöld villamos energia elöállitását, hogy egyrészt a zöld villamos energia valamennyi termelöje számára garantálja e villamos energia teljes mennyiségének a villamos energia piaci árát meghaladó, fix áron történő megvásárlását, másrészt pedig elöírja a villamosenergia-elosztók által így viselt költségek áthárítását a villamosenergia-fogyasztókra, a zöld villamos energia vásárlásához kapcsolódó kötelező felár révén, a Bizottság nem követett el hibát, amikor megállapította, hogy a nagy villamosenergia-fogyasztó vállalkozások, amely vállalkozások jogosultak arra, hogy kérelmükre ellentételezés fizetése révén mentesítsék öket a zöld villamos energia vásárlására vonatkozó kötelezettség alól, részére biztosított elöny ténylegesen állami források felhasználásával jár. Ez még akkor is így van, ha e támogatási mechanizmust egy olyan zöld villamosenergia-elszámolóközpont kezeli, amely központ feladatainak ellátása egy 50,4\%-ban magánirányitás alatt álló részvényesek tulajdonában lévő magánjogi részvénytársaságnak nyújtott konceszszió tárgyát képezte. A zöld villamos energia vásárlásához kapcsolódó kötelezö felár olyan, a villamos energiát terhelő parafiskális járulékhoz hasonlítható, amelyet közérdekü célokból hatóság határoz meg objektív kritérium alapján. Ennélfogva a szóban forgó összegeket állami forrásból származó, parafiskális járulékhoz hasonlitható eszközöknek lehet minősiteni.

Noha igaz, hogy a megújuló energiaforrásokból elóállított villamos energia gyártását elősegítő támogatási rendszer kezelésével megbízott szervezet magánjogi részvénytársaság formáját ölti, a zöld villamosenergia-elszámolóközpont feladatainak ellátása érdekében biztositott koncesszió keretében e szervezet magatartása nem a piacon nyereségszerzés céljából szabadon eljáró gazdasági egység magatartásának felel meg, hanem a nemzeti jogalkotó által a szóban forgó koncesszió végrehajtása terén körülhatárolt, korlátozott magatartásnak. E tekintetben az említett szervezet magatartásának az elöírt jogszabályi kereteknek való megfelelésére vonatkozó, különböző állami szervek által végzett, több szinten zajló szigorú ellenőrzés megerösiti azt a következtetést, hogy az emlitett szervezet nem saját nevében és nem szabadon jár el, hanem egy állami források révén nyújtott támogatás - koncessziót végrehajtó - kezelöjeként. E körülmények között a Bizottság megalapozottan állapította meg, hogy a nagy villamosenergia-fogyasztó vállalkozások részére biztosított előny a jelen ügyben kiegészitő terhet jelent az állam számára, mivel az általuk fizetendő adó összegének bármely csökkentése úgy tekinthető, mint amely bevételkiesést jelent az államnak (vesd össze 67., 68., 70., 72., 75., 76., 83. pont).

$A z$ állami támogatás fogalma nem vonatkozik olyan állami intézkedésekre, amelyek egyébként különbséget tesznek a vállalkozások között, és következésképpen a priori szelektív jellegüek, feltéve, hogy e megkülönböztetés a vonatkozó rendszer természetéböl vagy belső felépítéséböl ered. Az olyan adómentességek viszont, amelyek a vonatkozó adórendszertől idegen célkitüzés eredményei, nem mentesülhetnek az EUMSZ 107. cikk (1) bekezdéséből eredő követelmények alól. Egyébiránt a valamely adóintézkedés által biztosított elöny szelektív jellegének értékelése érdekében a viszonyítási alap meghatározása különösen fontos, mivel magának az elönynek a fennállását is csupán egy 'általános' adóztatáshoz viszonyitva lehet megállapítani. 
Így valamely nemzeti adóintézkedés 'szelektívnek' minősitéséhez elöször is elözőleg meg kell határozni és meg kell vizsgálni az érintett tagállamban hatályban lévő közös vagy „általános” adórendszert. Ehhez a közös vagy „általános” adórendszerhez képest kell ezután értékelni és megállapitani, hogy a szóban forgó adóintézkedéssel biztositott elöny szelektív jellegü-e. Ehhez pedig azt kell bizonyítani, hogy ez az intézkedés eltér az említett közös rendszertöl, mivel különbséget tesz az e tagállam adózási rendszere által kitüzött célra tekintettel hasonló ténybeli és jogi helyzetben lévő gazdasági szereplök között. $E$ tekintetben a vállalkozások között a terhekkel kapcsolatos különbségtételt bevezető tagállamra hárul annak bizonyitása, hogy a különbségtételt a szóban forgó rendszer jellege és felépitése ténylegesen igazolja” (96., 97., 117. pont). Az üggyel összefüggésben az Európai Unió Törvényszékének figyelembe kellett vennie a környezetvédelem állami támogatásáról szóló bizottsági iránymutatást is. ${ }^{55}$

\section{3. Állami támogatáshoz vezető előny biztositása kivételezés és aszimmetrikus adóztatás révén}

A csoportmentességi rendelet ${ }^{56} 25$. cikke értelmében a 2003/96/EK irányelv feltételeinek megfelelő, a környezeti adók csökkentése formájában nyújtott támogatási programokat a közös piaccal összeegyeztethetö támogatási programoknak kell tekinteni, és mentesülnek a bejelentési kötelezettség alól is. További feltétel, hogy az adócsökkentés kedvezményezettjének meg kell fizetnie legalább a 2003/96/EK irányelvben meghatározott közösségi minimum-adómértéket. $A z$ adócsökkentés legfeljebb tíz évre adható.

A 2014-2020 közötti időszakban nyújtott környezetvédelmi és energetikai állami támogatásokról szóló, említett bizottsági közleménybe (2014/C 200/01) foglalt iránymutatás 3.7.1. pontja értelmében támogatás nyújtható környezetvédelmi adókedvezmény vagy környezetvédelmi adó alóli mentesség formájában. A kedvezmények alkalmazásának célja ez esetben nem környezetvédelmi célú beavatkozás, hanem ellenkezöleg, a környezetvédelmi követelmények alóli - rendesen részleges és ideiglenes - mentesítés. Zavarban lehetünk a bizottsági iránymutatással kapcsolatban, ugyanis, ha a kedvezmény a környezetre káros tevékenységet sújtó adózási intézkedésekkel szemben kedvezményt biztosit, akkor valójában nem mutatható ki környezetpolitikai cél. Éppen ellenkezöleg, ez esetben az iparpolitikai, illetve szűk értelemben vett versenyképességi szempontok elnyomják a környezetpolitikai szempontokat. ${ }^{57}$

55 Lásd a közösségi iránymutatást a környezetvédelem állami támogatásáról: HL C 82, 2008. 04. 01. A jelenleg hatályos iránymutatás a Bizottság közleménye a 2014-2020 közötti időszakban nyújtott környezetvédelmi és energetikai állami támogatásokról: HL L 200, 2014. 06. 28., 1.

56 A Bizottság 800/2008/EK rendelete (2008. augusztus 6.) a Szerződés 87. és 88. cikke alkalmazásában a támogatások bizonyos fajtáinak a közös piaccal összeegyeztethetőnek nyilvánításáról (általános csoportmentességi rendelet). HL L 214, 2008. 08. 09., 3.

57 „It is [...] puzzling how exemption from environmental taxes can protect the environment. Moreover, the justification for this exemption is often based on weak reasoning." [Zavarba ejtő kérdés, hogy a környezeti adó 
Érdemes megemlíteni azt a problémát is, hogy amikor a kedvezmény célja előny biztosítása azon piaci szereplők javára, akik hozzájárulnak az ökológiai egyensúly javításához (például azért, mert megújuló energiát hasznosítanak), a megkülönböztetés szintén állami támogatást valósíthat meg, és csak esetről esetre lehet elbírálni, hogy a környezetpolitikai megkülönböztetés révén bekövetkező versenykorlátozás igazolható-e (lásd erre például a Kernkraftwerke Lippe-Ems ügyet, amelyben az Európai Unió Bírósága megállapította, hogy a tagállami hasadóanyag-adó nem kifogásolható). A kérdéses bizottsági iránymutatás nem az ilyen esetekre vonatkozik. A T-251/11. sz., Osztrák Köztársaság kontra Európai Bizottság ügyben tárgyalt, a nagy villamosenergia-fogyasztó vállalatok számára a zöld villamos energiáról szóló osztrák törvény szerint nyújtott támogatás esetében figyelembe kell venni a bizottsági iránymutatást, mert a nagyfogyasztó müködése nyilvánvalóan nagyobb terhelést jelent a környezetre, mégis az iránymutatás szerint adott esetben - de nem a tárgyalt jogesetben - méltányolható lehet a kedvezményezés igazolása.

Állami támogatáshoz vezető előny nemcsak úgy keletkezhet adóztatási folyamatban, hogy az adókötelezéssel szemben az adóalapban, az adómértékben vagy az adókötelezettség időzítésében az állam egyes adózóknak kedvezményt biztosít, hanem úgy is, hogy az adóalapot az állam olyan szüken állapítja meg, hogy egyes piaci szereplök kiesnek az adóztatásból, miközben esetleg más piaci szereplőkhöz viszonyítva e szereplők versengő termékeket állítanak elő, utóbbiak pedig ugyanakkor adófizetésre vannak kötelezve. Környezetpolitikai szempontból legalább annyira fontos lehet a megkülönböztető - aszimmetrikusnak is nevezhető - adóztatás, mint adóelőnyök biztosítása egyes környezetterhelő tevékenységet végzők javára. $A z$ aszimmetrikus adóztatás szintén vezethet olyan elönyhöz, amely adott esetben tiltott állami támogatásnak minősülhet. ${ }^{58}$

Tipikus esetben tiltott állami támogatás azért állapítható meg, mert a vizsgált környezeti adóval szemben biztosított kedvezmény tényleges hatását illetően kivételes előnyt jelent a kedvezményezetteknek azokkal az adófizetőkkel szemben, akik nem élvezhetik e kedvezményt. Aszimmetrikus adóztatás esetén nem a tényleges hatásból kell kiindulni, amennyiben e tekintetben kivételezés nem mutatható ki, hanem a bevezetett adóhoz füződő jogpolitikai célból. Ha ugyanis a jogalkotó által meghatározott célok nem eléggé átfogóak, akkor megkülönböztető adóztatásra következtethetünk, ami vezethet tiltott állami támogatáshoz, ahogy ez történt egy elemzett görög esetben is.$^{59} \mathrm{~A}$ jogalkotói célkitúzés fragmentált volta problémához vezetett a British Aggregates Association esetben is, de ott az Európai Unió Bírósága végül a versenykorlátozó joghatás alapján döntött az állami támogatás megállapíthatóságáról, anélkül hogy a jogalkotói célokra nézve külön vizsgálta volna azok átfogó jellegét.

alóli kivétel milyen formában alkalmas a környezetvédelmi célok megvalósítására. Ráadásul a mentesülés igazolása gyakran gyenge érvekre támaszkodik - a szerk.] NicolAIDES, Phedon: In Search of Economically Rational Environmental State Aid: The Case of Exemption from Environmental Taxes. European Competition Journal, 2014/10, 164.

58 Nicolaides, Phedon-MetaxAs, Antonis: Asymmetric Tax Measures and EU State Aid Law. The „Special Solidarity Levy" on Greek Producers of Electricity from Renewable Energy Sources. European State Aid Law Quarterly, 2014/13, 51.

59 Nicolaides-Metaxas: i. m., 51. 


\section{Következtetések}

Tanulmányom az ökoadókkal foglalkozik, és azokra úgy tekint, mint amelyek a fiskális politikának a zöld gazdaság szolgálatába állítható eszközei. Eszerint megengedhető az, hogy az ökoadók a rendelkezésre álló erőforrások felhasználásával elérhető maximumhoz képest a gazdasági teljesítményt akár visszafogják, ha egyébként képesek hozzájárulni az ökológiai egyensúly helyreállításához. A tanulmányban érvényesített ökológiai szemléletnek megfelelően a gazdasági teljesítmény értékelésének nem lehet kizárólagos vagy akár csak meghatározó szempontja az előállítható hasznosságok maximalizálása. Ehelyett az univerzális etikai értékek jegyében (elővigyázatosság és szubsztantív felelősség, integráció elősegítése, partnerség stb.) számolnunk kell azzal, hogy a gazdasági növekedés hogyan hat a biotikus életközösségekre.

A hatásos ökopolitika érvényesítésének akadálya az olyan makro- és mikrogazdasági szemlélet, amelyet alapvetően a piaci szempontok határoznak meg. E nézőpontból az alkalmazandó adóknak és más környezetpolitikai intézkedéseknek úgymond semlegeseknek kell lenniük, vagyis elvárás az, hogy az állami beavatkozás ne torzítsa el szükségtelenül a gazdasági versenyt. Mivel ugyanezen felfogás érvényesül az Európai Unió joggyakorlatában is, a környezetpolitikai szempontok átfogó és hatásos érvényesítése ma még nagyrészt lehetetlen.

Tanulmányom feltárja azt az ellentmondást, hogy a környezeti adók igazolása máig piackonform feltételezéseken nyugszik, miközben a piacgazdaság által produkált globális ökológiai válság egyre feltünőbb jeleivel találkozunk. Az egyes fiskális politikai intézmények részleteinek kidolgozása szempontjából sokszor mindegy - vagy közömbösnek látszik -, hogy piacbarát vagy ökológiai szemlélet révén kívánjuk-e igazolni a tényleges környezeti politikát. Az elvi megalapozás és a jövőbe mutató tervek kidolgozása azonban nem lehetséges a kívánatos paradigmaváltás nélkül.

A gazdaság stabilizálása alapvetően az egyensúly fenntartását célozza, ideértve az ökológiai egyensúlyt és fenntartható növekedést is. Makroökonómiai nézőpontból a figyelmünk arra irányul, hogy az adómix átrendezésével lehetséges felszabadítani olyan terheket, amelyek jelenleg a munkára, a tőkére és az értékesítésekre rakódnak rá. Mikroökonómiai megközelítésben az adókivetést követő jóléti maximalizálás lehetőségét keressük, egyensúlyt keresve a negatív externáliák megszüntetése és az adott termelésre az adóztatással rárakódó ráfordítás között.

A makroszemlélet mögött az önszabályozó piac idealizálásának feltételezése húzódik meg. Ebből kiindulva a tőke és munka szabad kibontakozása előtt tornyosuló akadályok eltávolítása közhaszonnak tekinthető. E felfogás csak korlátozott mértékben lehet alkalmas az ökológiai problémák megközelítésére. A mikromegközelítés mögött a pareto hatékonyság eszméje húzódik meg, amely a piaci alku tökéletességének elméleti feltételezésén alapul. Az elképzelést kiszolgáló, a piacgazdaságban elérhető nyereségmaximalizálásnak alárendelt racionalitás segítségével azonban csak kevéssé lehet megérteni az ökológiai problémákat.

A fentiekben áttekintett uniós jogi esetekből az látható, hogy az ökopolitika érvényesítése az Unió keretei között igen sok tekintetben akadályba ütközik. Az Unió müködésének középpontjában ugyanis a versenyszabadság áll, hiszen lelkét az 
alapvető szabadságok képezik. E háttérből kell értékelni az adóharmonizáció szükségességét és a versenypolitikát, e tekintetben kitérve az állami támogatások kérdésére, és ezen belül arra, hogy adókedvezmények révén is megvalósulhat állami támogatás, ami alapesetben tilos. A környezeti politika ma még egyértelmüen alá van rendelve a versenyszabadság értékének, amint ez világosan kitűnik például a British Aggregates Association ügyében meghozott ítéletből: „...a környezetvédelemmel kapcsolatos követelmények figyelembevételének szükségessége - még akkor is, ha azok jogszerüek - nem indokolja a szelektív jellegü intézkedések - akár az olyan speciális intézkedések, mint a környezetvédelmi adók - kizárását az EK 87. cikk (1) bekezdésének hatálya alól" (92. pont).

Az ökopolitikát keresztező adóharmonizáció két alapvető csatornája az energiaadó (Fendt, Flughafen Köln, Plantanol, IRCCS, Kernkraftwerke Lippe-Ems) és az ásványolajtermékeket érintő (Braathens, Transportes Jordi Besora, Statoil) jövedéki adózás. Ökoadót csak akkor vezethet be egy tagállam, ha az eléggé sajátos ahhoz, hogy ne zavarja a harmonizált energiaadó és jövedéki adó müködését. A másik komoly korlát az, hogy a differenciált környezetvédelmi politikáról könnyen és sokféle okból megállapítható, hogy az adóztató állam egyes piaci szereplőknek szelektív előnyt biztosít, és így a versenyszabadságot torzító intézkedésnek minősül (AdriaWien Pipeline, British Aggregates, Kernkraftwerke Lippe-Ems, T-251/11. sz., Osztrák Köztársaság kontra Európai Bizottság ügy). Az is lehet, hogy az ökoadóvámmal azonos hatást kiváltó díjnak minősül (Kernkraftwerke Lippe-Ems), ami szintén tilos, vagy esetleg olyan termékadónak, amelyröl viszont az állapítható meg, hogy a tagállamok közötti forgalomban hátrányos megkülönböztetéshez vezet (Frohnleiten).

Az alapvető problémát az jelenti, hogy az uniós jog a piaci müködés tökéletességére irányuló ki nem mondott feltételezésen nyugszik, ha pedig egy tagállami intézkedés beleütközik a versenyszabadság értékébe, akkor a tagállami intézkedést kell visszavágni ahhoz, hogy a piaci szabadság elött lévő, adózás tekintetében adminisztratív természetü akadályok elháríthatók legyenek. Elakad viszont az uniós jogi mechanizmus akkor, ha a beavatkozás nem azért szükséges, hogy több piaci szabadság legyen teremthető, hanem - ellenkezőleg - azért, hogy kevesebb. A termodinamikai korlátok felöl nézve pedig nyilvánvaló, hogy a piaci tökéletlenség nem zárható ki, ebből adódóan pedig a kívánatos beavatkozás célja nem a piaci szabadság helyreállítása, hanem a piaci müködés korrekciója. Ennek politikai és jogi alapja elméletileg és a gyakorlatban is máig hiányzik az Unióban, ami komoly probléma.

A költségvetési bevételek hosszú távon várható csökkenése párhuzamos lehet azzal a felismeréssel, hogy a növekedés nem öncél, és át kell állnunk egy nem növekedésközpontú gazdaságra, újraértékelve humán céljainkat. $E$ felismerés fényében kritikusan kell viszonyulnunk a gazdasági növekedéshez még annak fenntartható, tudásalapú és befogadó formájában is, és nem a növekedéstöl várjuk a gazdasági és társadalmi problémák megoldását, hanem a háztartási és ökológiai egyensúly helyreállitására irányuló, egyébként nagyon bonyolultnak ígérkező tervektől és intézkedésektöl. Ennek keretébe illeszthető a fiskális politika zöldebbé alakítása. Ezen túlmenően a környezethez való viszonyunk radikális megváltoztatására van szükség, figyelembe véve, hogy a természet nem kiaknázandó tárgy, hanem éltető közeg, amelyben az élölények sorsközösséget alkotnak. Ezért a formális jogi in- 
tézkedések mellett nagy szükség van önkéntes jogkövetésre, önszabályozásra és a vitarendezés olyan formáira, amelyek túlterjednek az állami intézkedések hatókörén.

\begin{abstract}
The subject of the present paper is the explanation and justification of environmental taxes in general terms and, in particular, the assessment of the recent European trends as well as the examination of the practice of the EU Court of Justice followed in this field. The paper considers ecotaxes as the means of fiscal policy that can be put into the service of green growth. For the time being, the enforcement of ecological policy is restricted in many aspects within the EU framework, being unilaterally subordinated to the requirement of free competition. For this reason, the EU law mechanisms of adjustment may get stuck in cases where intervention is not necessary in order to have more but, on the contrary, to have less freedom of market. Since it can be considered as obvious from the perspective of thermodynamic restraints that market imperfections cannot be precluded, the possible aim of intervention is certainly not the reconstruction of free trade, but the suspension of the laws of market. The political and legal basis for this is still missing in the European Union both in theory and practice what can be seen as a serious problem.
\end{abstract}

